\title{
High energy, increased balance and self control, the necessary conditions for performance and a good health
}

\author{
Lucian T. MÂNDREA \\ Politehnica University of Bucharest, Bucharest, Romania \\ mandrea_lucian@hotmail.com,lucian.mandrea@upb.ro \\ Ioan I. CURTA \\ Transilvania University of Brașov, Brașov, Romania \\ icurta@yahoo.com \\ Zoltan Z. MAROSY \\ Ecological University of Bucharest, Bucharest, Romania \\ marosy.zoltan@gmail.com
}

\begin{abstract}
The research purpose is to present the possibilities of the human being which are useful in order to improve the personal level of energy and to achieve an increased balance and a strong self control. These are the necessary conditions to be performed and in the same time to maintain a good health. Humans usually use energy from external sources. But, first of all, by employing different personal techniques, one can reach a high level of balance, energy and self control. These are the simplest, the fastest, the most efficient, the most economical and also ecological ways to have energy. If these attempts are efficient, you are first of all warm, then less ill and stressed. Everybody should try these kinds of methods first. A comparison was made between the results from two consecutive years, obtained by measuring the subject using a Bio-Well device. It results an increase of $23 \%$ in the energy level, in the conditions that the other parameters are optimal. The general balance reached the value of $99.97 \%$. The authors proved, with the occasion of these original measurements, that a perfect balance can be reached. Another set of original and new measurements reveal the possibility of the human being to have a good self control. The subject proposed and succeeded in moving the second body energy centre by his own will, which is the most important energy centre of the body in the Zen-Buddhism. This is a remarkable completely original result obtained, maybe, for the first time in the world. In principle, we could control then the positions of the all seven energy centers, one by one. And so, the whole balance of the body. Also, in this way an incredible personal control and level of performance and also a high level of happiness can be achieved.
\end{abstract}

Keywords: energy, balance, self control, performance, health, excellence, Bio-Well device.

\section{Introduction}

The authors first purpose is to show that if even diverse persons advance in age, they can have good results regarding the own energy, the intern balance, the level of stress, the increased self control and a better health. The own energy shell can also be a focus.

Therefore, success can grow in time continuously, contrary to the others' different opinion in what concerns the age. Previous achievements are premises for a high level of performance in business excellence and not only.

Different methods can be used by everybody. For instance, beams of energy can be sent from the region of the abdomen to repair the energy shell of the body. They can be also directed to different internal organs to improve their functioning, one by one [Mândrea\& Torp, 2016].

The region of the abdomen is very important since it is there that the second body energy center is placed, which is the main center in the Zen Buddhism. The place 
corresponding with the second body energy center is called also "My own place". This is the headquarters of the entity which leaves our body when we die [Mândrea\& Chirilă, 2017], [Mândrea, 2014], [Mândrea, 2011] and which we can use to control everything inside the physical body to obtain good results in terms of health. Comments about the types of orbs can be found in the papers of different authors [Petre, 2014], [Klaus\&Miceal, 2007], [Jeremy 2011].

The authors propose other original methods, discovered by the first author of the

PICBE $\mid 580$ article in time, to improve the human being's general functioning. For example, the method of the wire slowly stretched out can be used to increase the own balance.

The methods of enlarging the zone of the third eye, or of enlarging the zone of the soul exit from the body can be used to have a very good physical body relaxation.

The last two methods are also very useful to fall asleep again during the night without taking any pills. Different human being aspects and behaviors correlated with this type of article were presented in time by the authors of this article [Mândrea\& Curta, 2017], [Mândrea, et al., 2015], [Marosy, 2010].

Other aspects related to the functioning of the human being were also highlighted by others authors [Becker, 1985], [Dobson\&O'Keffe, 2000], [Dumitrescu, 1979], [Gerber, 2005], [Guja, 1993], [Guja, 2000, a], [Guja, 2000, b], [Guja, 2008], [Ionescu-Târgoviște, 1986], [Lupeanu, 2008], [Manu, 2007], [Mămulaș, 2008], [Motoyama, 2009].

The inventor of the Bio Well device published in time different materials correlated with our subjects, too. [Korotkov\&Korotkin, 1989], [Korotkov, 2007].

Besides, to achieve a very good balance of the body, we indicate the control method of the main seven energy centers positions, as well.

In this sense, two original examples are presented in the second part of the article, both referring especially to the second energy centre of the body.

Two movements in the same sense of this centre position were made by the first author of the article, for two consecutive weeks, to demonstrate that the action was not random.

They were effected in the pro-active and then in the pro-passive zone of the body. We thus succeeded in achieving unique, very important and original results, justified with the values obtained by means of the Bio-Well device.

\section{Measurements and Results}

First of all, we are comparing the results from two consecutive years, 2016 and 2017, obtained by measuring the subject, in our case the first author of the article.

The first sets of measurements, concerning especially the energy and then the general balance of the subject, were made using a Bio-Well device, also called an EPI Device.
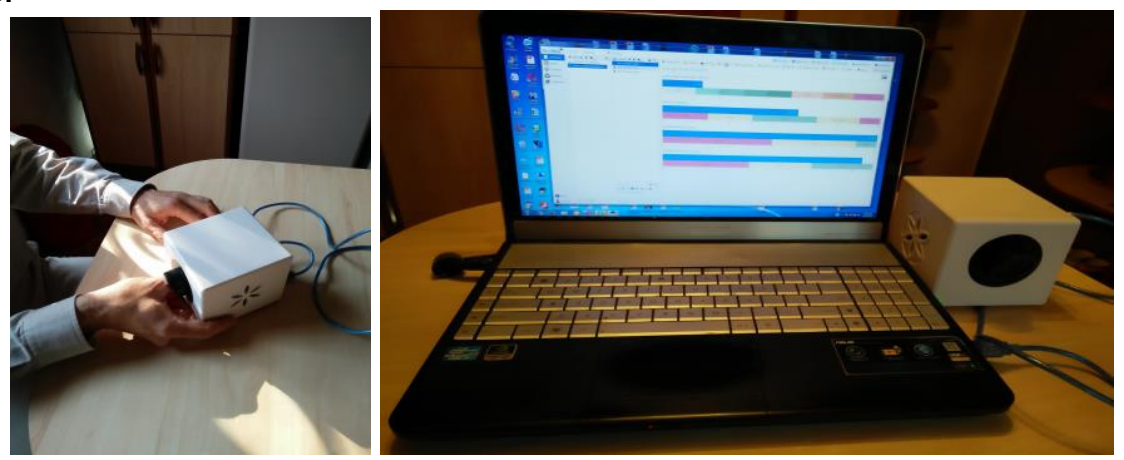

Figure 1. The Bio-Well device and the laptop with the measurement results

Source: Authors' own research. 
The Bio-Well device, or the Electro Photonic Imaging by Gas Discharge Visualization, uses weak and painless electrical currents. They are applied to each of the ten hand fingertips for less than a millisecond. The fingers are introduced one by one in the device, as shown in Figure 1.

The human body responds by forming an "electron cloud" which is composed of light energy photons. The "glow" of the discharge which is invisible for the human eye, is PICBE $\mid 581$ registered with an optical camera system. It is then sent to a computer to be analyzed.

We can see, as presented in Figure 1, the graphical representations of the stress, energy, general balance, organs balance and health state of a person which is characterized by a lot of parameters. The level of energy for every organ can be visualized, too. The general aspect of the body energy shell can also be seen as an aura [Korotkov, 2014]. These results represent a holistic view of that person's wellbeing state and this is useful in establishing a quick diagnose of the person's health [Yakovleva\& Korotkov, 2013].

The Bio-Well device was developed based on the Kirlian effect, discovered at the middle of the last century. These devices are constructed to offer details about the human energy field and allow the visualization of this field under the influence of different stimuli.

By employing the Kirlian effect, the UCLA researchers, T. Moos and K. Johnson, after over 10, 000 experiments, reached the conclusion that the energy of a subject is in direct connection with the psychic state of the subject. The glowing which appears on the Kirlian photo can be also connected with hypnosis, meditation or alcohol ingestion.

The experiments performed by Professor Konstantin Korotkov pointed out important differences between the magnitude and luminosity of the Kirlian photos of the same subject, taken before and after acupuncture treatments.

A huge leap was made when the statistic correlations between the finger tips and different organs of the human body were set in connection with the Kirlian photos.

These correlations were discovered by Doctor Voll and Doctor Mendel at the middle of the last century starting from the principles of the traditional Chinese medicine and traditional Indian medicine.

Professor Korotkov gathered in the GDV devices the Kirlian effect, the gas discharge and the processing of the images or photos obtained by means of specialized software programs which use fractal mathematics and nonlinear mathematical analysis.

The device was previously utilized by the first author and collaborators but with narrow purposes [Mândrea\& Curta, 2017], [Torp et al., 2016], [Torp et al., 2015].

The measurement procedure respected the requirements of the device inventor, Professor Korotkov [Korotkov, 2002]. All the GDV-grams of our measurements subject were taken by the same operator, in the same room with constant temperature and humidity, content and quality of the air. The subject felt comfortable and was emotional calm and exterior influences were inexistent. The smoke and alcohol were excluded. The subject was always measured in the first part of the day and he took no pills. All the rules were respected in order to obtain very good measurements.

In Figure 2, we show first the results obtained in 2016, regarding the general state of the subject. The emotional pressure, also called the stress, the level of energy, the general and organ balance or equilibrium are presented: 


\subsection{4}

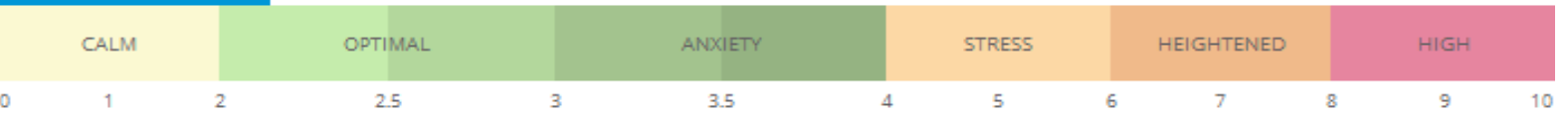

ENERGY: Optimal

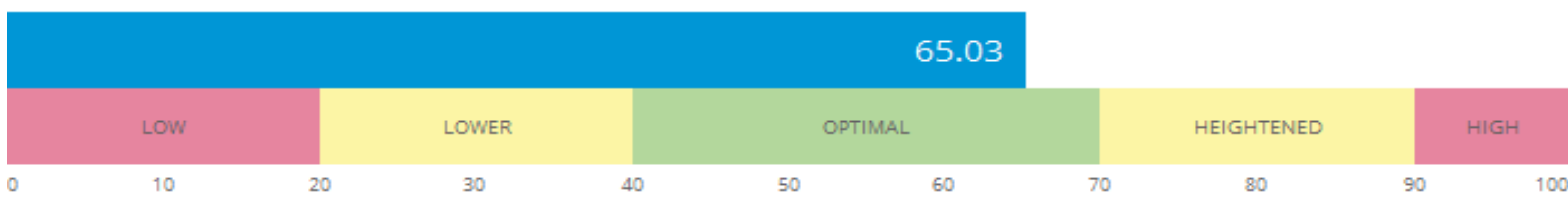

L/R SYMMETRY: Optimal

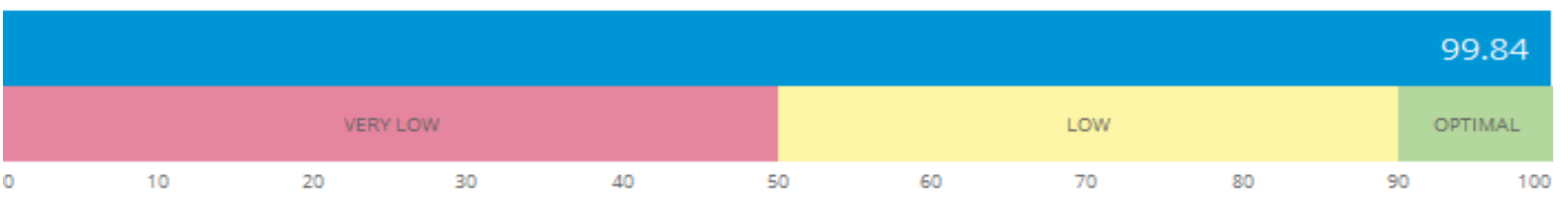

ORGANS BALANCE: Optimal

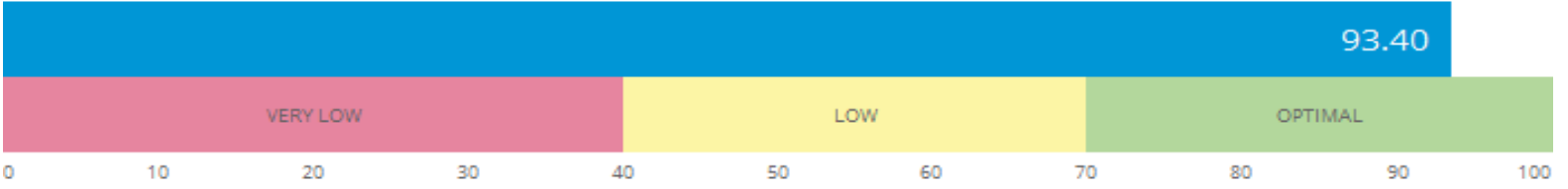

Figure 2. Electro Photonic Imaging Device state data, recorded in July 2016 (The article's first author)

Source: Authors' own research.

We shall compare these results with another two sets of results obtained by the same person in 2017.

A significant set of four measurements follows, with an increased level of energy, compared to the previous year, as we can see in Figure 3.

They were also made in the conditions of a continuous decreased stress and a growing organs balance. The level of energy passes from the optimal zone to the heightened zone, for the last three measurements.

As we can see, the maximum level of energy obtained was of $73.97\left(10^{-2} \mathrm{~J}\right)$. It can be approximated at 74 . Compared with value 65 from the year before (Figure 2), it results an increase of $12 \%$, in the conditions that the other parameters are optimal. 


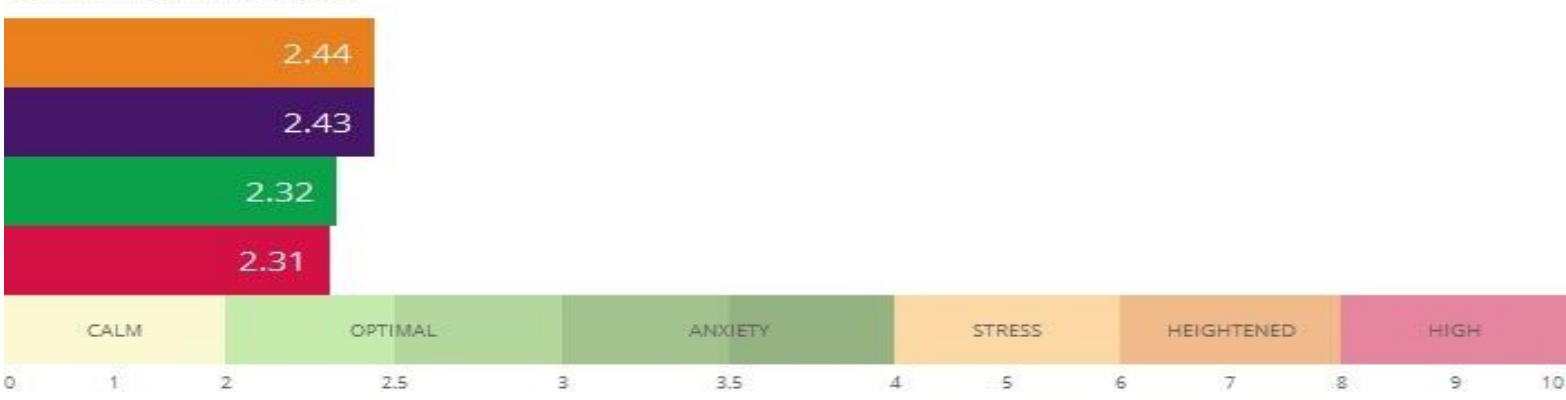

ENERGY

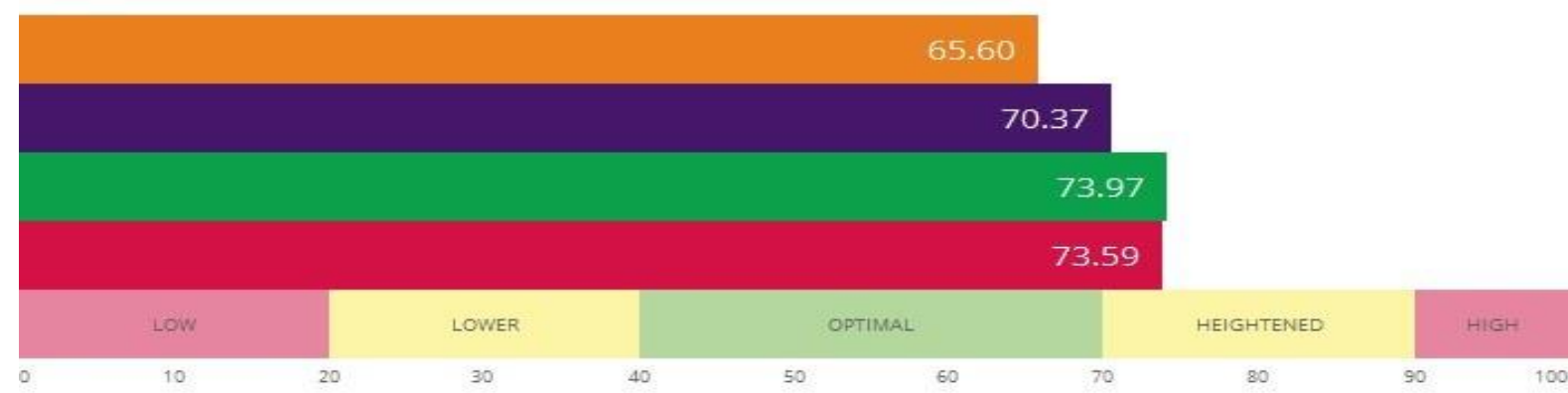

L/R SYMMETRY

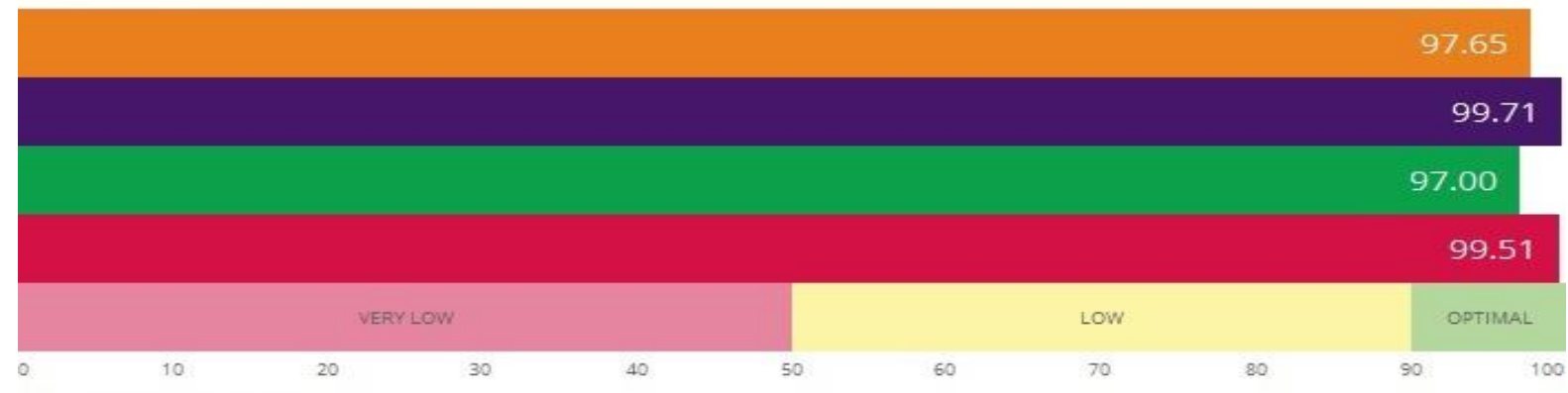

ORGANS BALANCE

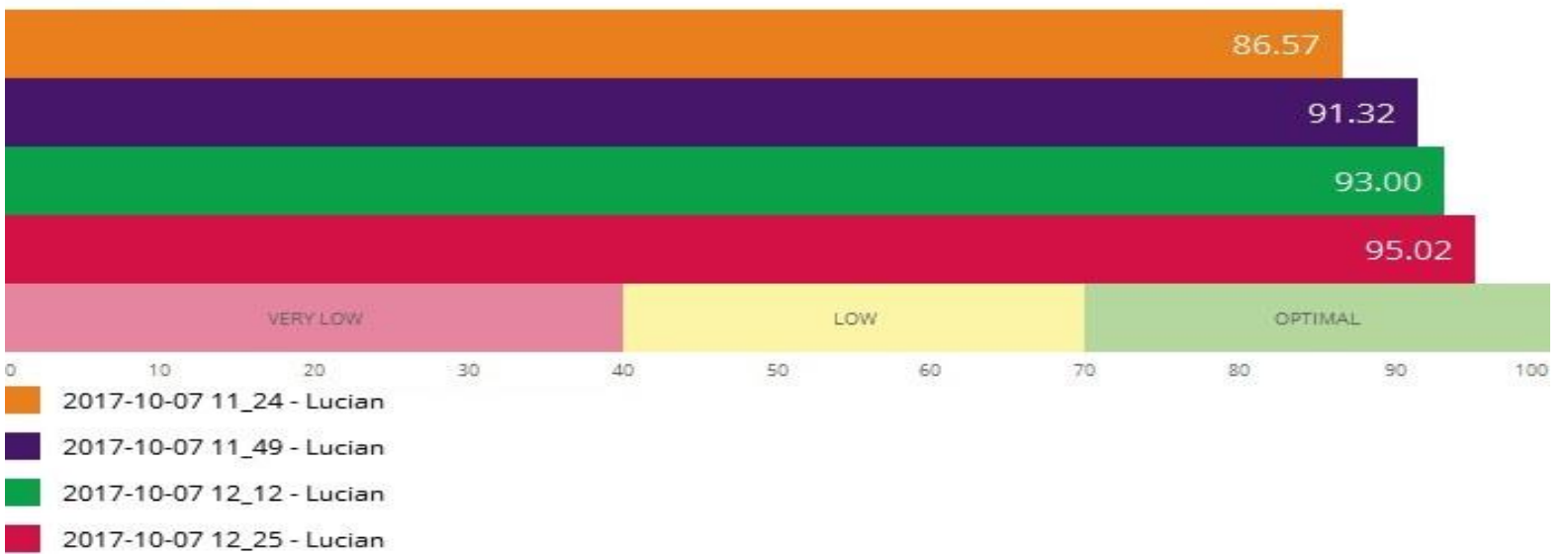

Figure 3. Electro Photonic Imaging Device state data, recorded in July 2017 (The article's first author)

Source: Authors' own research.

Another significant set of two measurements follows, with another increased level of energy, compared to the previous year, as we can observe in Figure 4. They were also made in the conditions of an approximate same level of stress and a growing organs balance. 


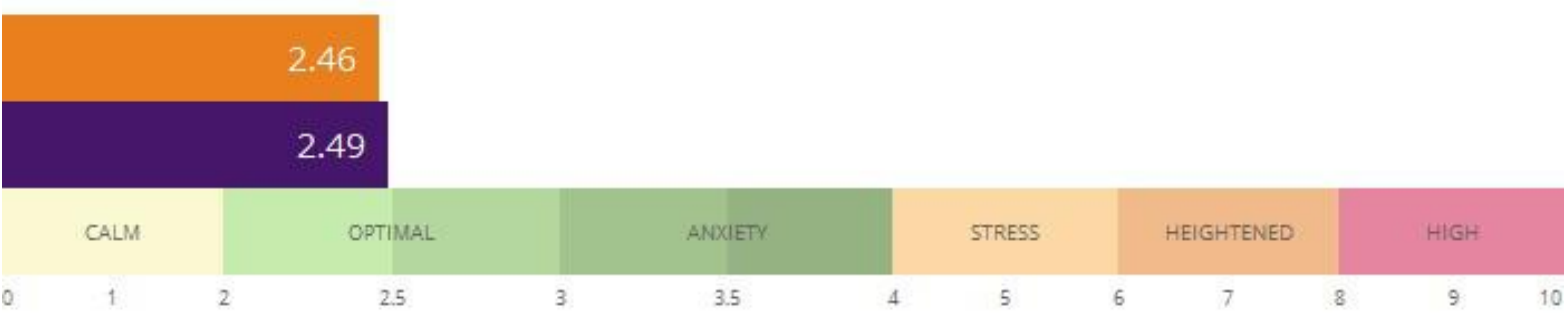

PICBE | 584

ENERGY

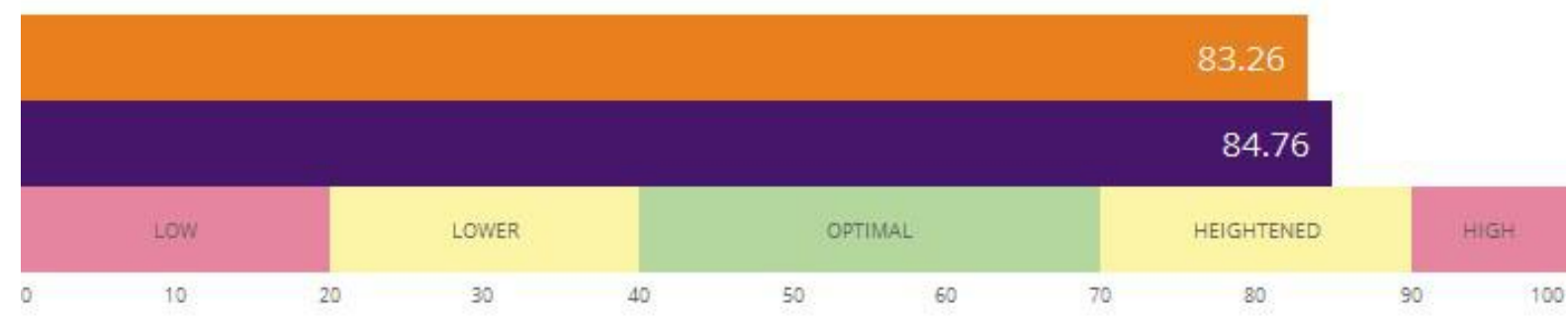

L/R SYMMETRY

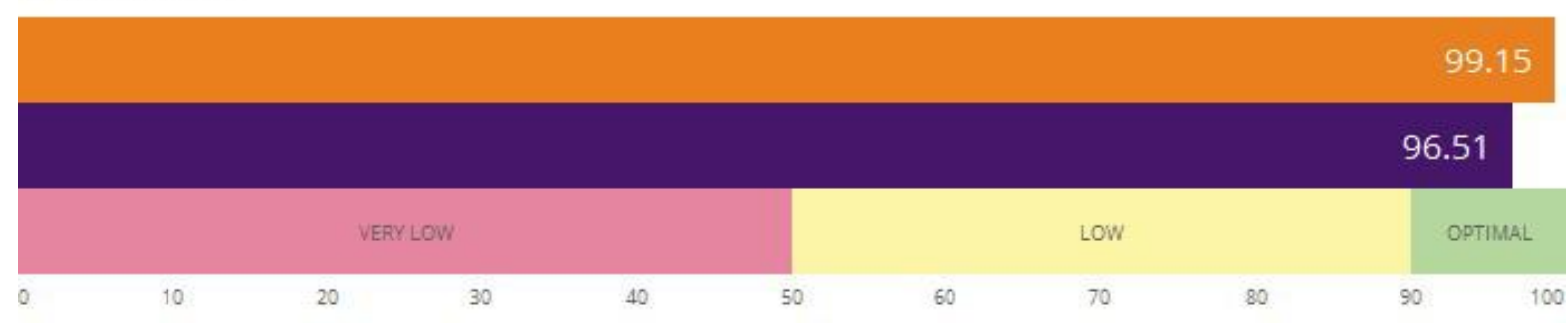

ORGANS BALANCE

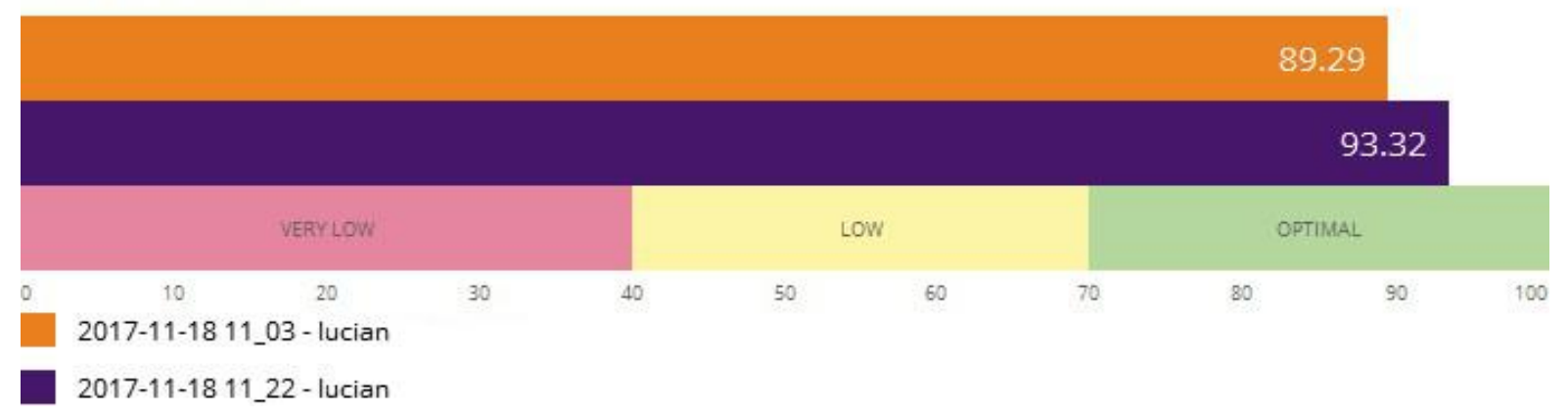

Figure 4. Electro Photonic Imaging Device state data, recorded in November 2017 (The article's first author)

Source: Authors' own research.

The level of energy is already in the heightened zone for both measurements and is closing to the high zone.

As we can see, the maximum level of energy obtained was of $84.76\left(10^{-2} \mathrm{~J}\right)$. It can be approximated at 85 . Compared with the value 65 from the year before from Figure 2, it results an increase of more that $23 \%$, in the conditions that the other parameters are optimal.

We consider this growth of $23 \%$ of the person's energy in one year and a half to be a very large one.

We also immediately observe, in Figure 5, that the energy shell has no breaks and is very consistent, at the last levels of energy presented in Figure 4. 

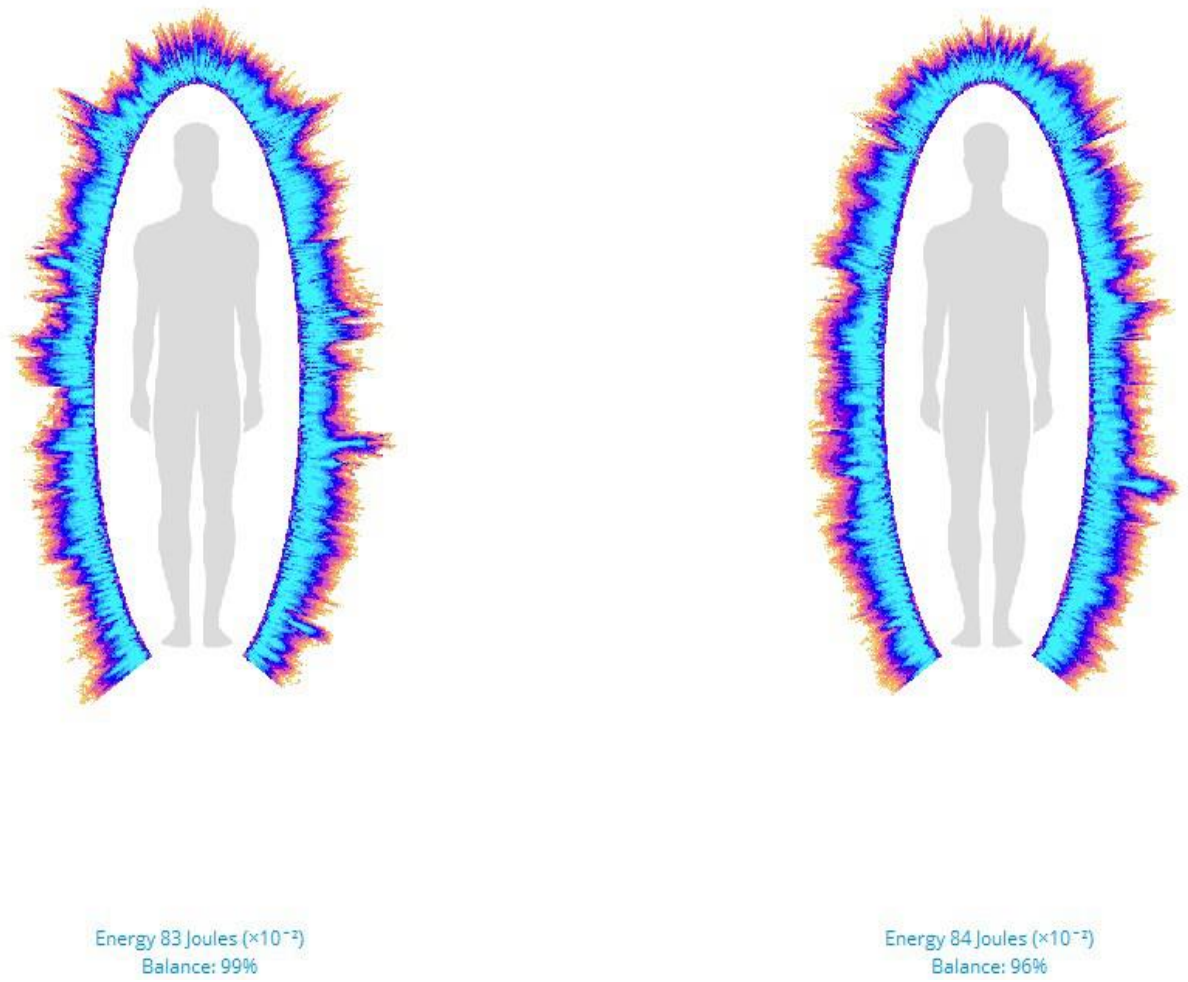

PICBE | 585

Figure 5. Electro Photonic Imaging Device energy shell, recorded in November 2017 (The article's first author)

Source: Authors' own research.

Every level of high energy corresponds to a high level of the body's general balance, as we can see at the bottom of Figure 5 .

For the next comparison, we must notice in Figure 2 that in July 2016 the left/right symmetry has the level of $99.84 \%$ and the organs balance the level of $93.4 \%$.

This comparison refers to other significant measurements made with the first author of the article in 2017, which deal with the internal general balance or the left/right symmetry and organs balance, as shown in Figure 6.

We can see that for the third measurement, at the minimum level of the emotional pressure, or stress, the general balance reached the value of $99.97 \%$. Only $0.03 \%$ is missing to reach the value of $100 \%$. This means a perfect balance.

The authors proved with the occasion of these other original measurements, that a perfect general balance can be reached.

The organs balance also reached during all the last three measurements a maximum value of $95.98 \%$, (dark violet in Figure 6).

A perfect balance means less illness, increased energy and diminished stress. These things also mean that we are in a continuous state of a very good health.

These achievements represent, of course, the necessary conditions for performance.

All these things were done by also maintaining the energy shell of the body in a very good condition [Mândrea, Chirilă, 2017]. 


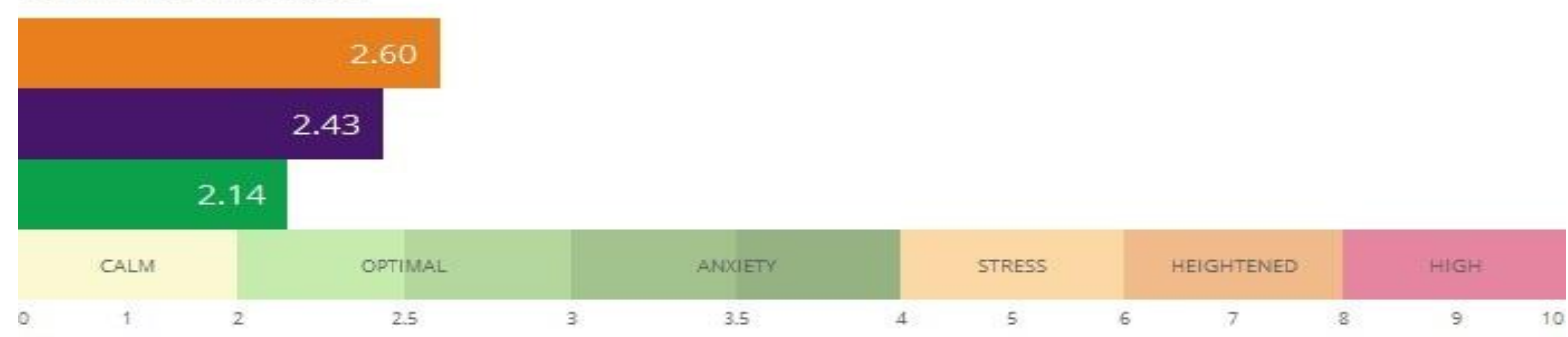

ENERGY

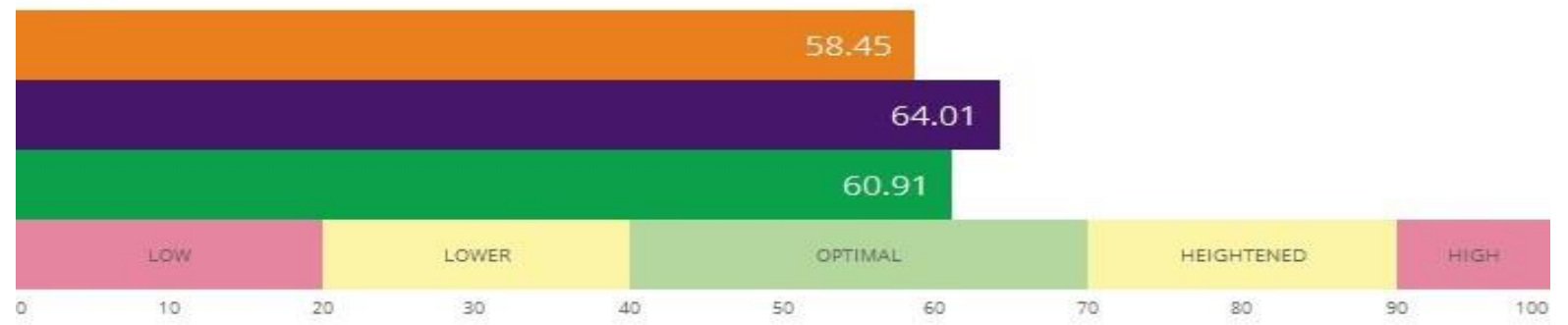

L/R SYMMETRY

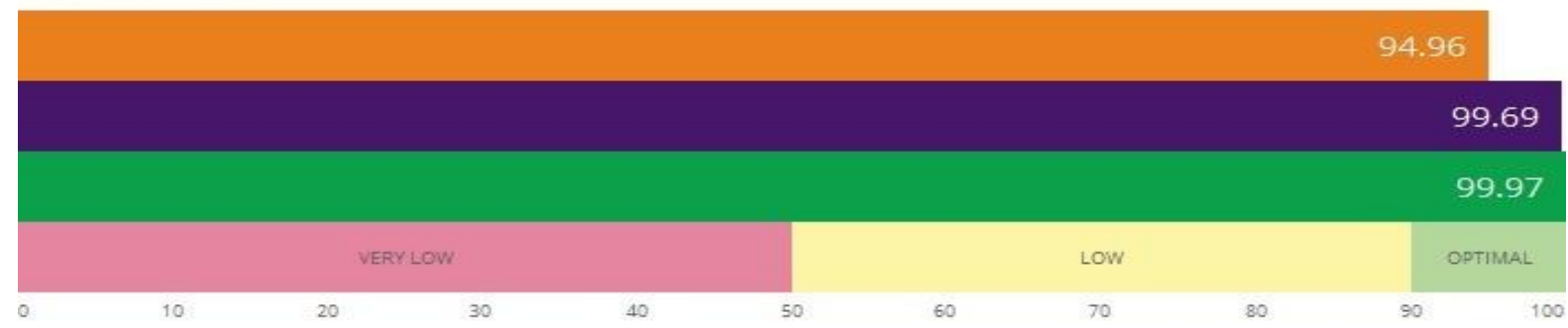

ORGANS BALANCE

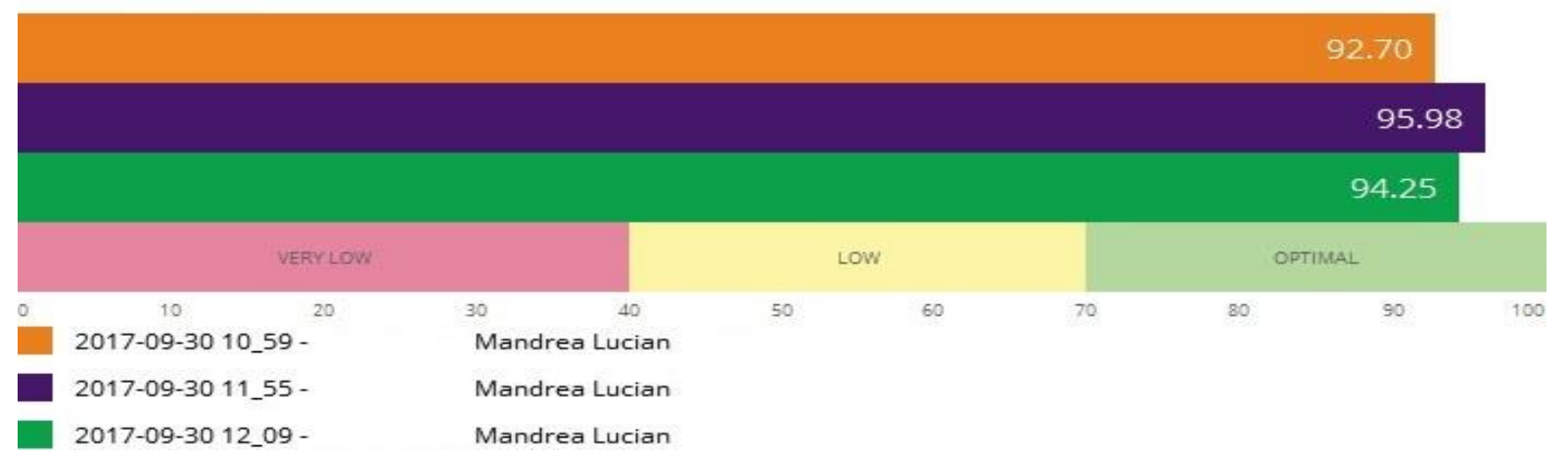

Figure 6. Electro Photonic Imaging Device state data, recorded in September 2017 (The article's first author)

Source: Authors' own research.

The second part of the article presents another set of original and new measurements which reveal the possibility of the human being to have a very good self control.

The first author of the article proposed and succeeded in moving the second energy centre of the body by his own will, which is the most important energy centre of the body in the Zen Buddhism.

In the first set of these three measurements, the subject moved the position of the second energy centre in the pro-active zone, two movements in the same direction, as presented in Figure 7. 


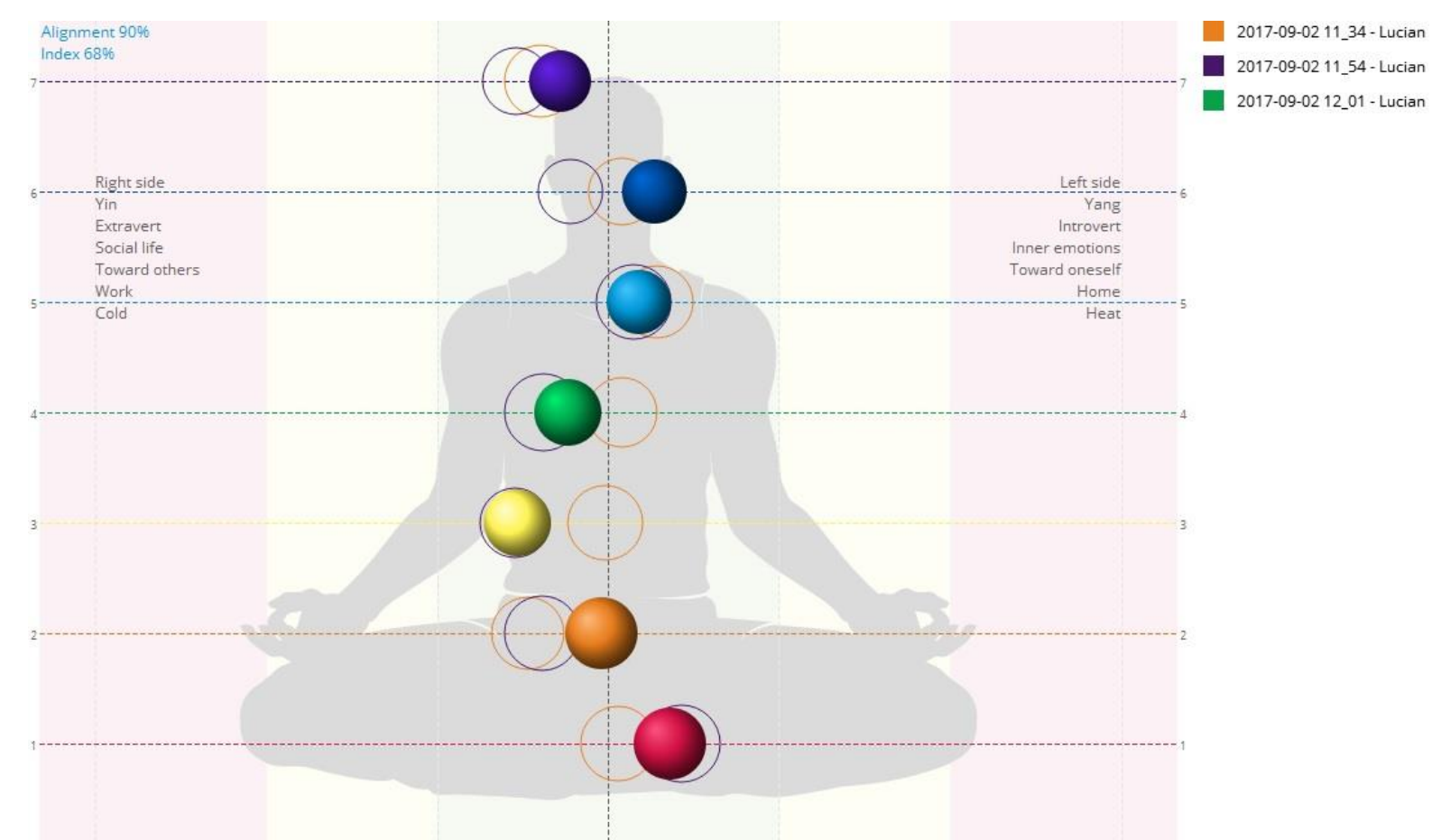

PICBE $\mid 587$

Figure 7. Electro Photonic Imaging Device state data, recorded in September 2017 (The article's first author)

Source: Authors' own research.

We can see that the other centers have completely different movements, in general alternative movements, left or right compared to the first position.

Table 1. The seven energy centers alignment for the first 3 measurements

\begin{tabular}{|l|c|c|c|}
\hline \multicolumn{1}{|c|}{ Energy centre } & \multicolumn{3}{|c|}{ Alignment } \\
\hline & First position & Second position & Third position \\
\hline The first, red & 98.26 & 85.89 & 88.20 \\
\hline The second, orange & $\mathbf{8 4 . 0 5}$ & $\mathbf{8 6 . 9 0}$ & $\mathbf{9 8 . 4 2}$ \\
\hline The third, yellow & 99.30 & 81.52 & 82.21 \\
\hline The fourth, green & 97.57 & 87.19 & 91.92 \\
\hline The fifth, blue & 90.65 & 95.13 & 94.12 \\
\hline The sixth, ultramarine & 97.49 & 92.36 & 91.21 \\
\hline The seventh, violet & 86.59 & 81.94 & 90.45 \\
\hline
\end{tabular}

Source: Authors' own research.

For energy centre number 2, the difference of the extreme values (between the first position and the third position) is of $14.37 \%$, as shown in Table 1.

We consider the value high enough to justify the wanted displacement of this center.

The first position in the table corresponds to the orange empty circle, the second to the violet empty circle and the third to the green empty circle, which is covered by the full orange disk, as presented Figure 7.

In the second set of three measurements, taken after a week, the author moved the position of the second energy centre in the pro-passive zone, two movements in the same direction, as we can see in Figure 8. 


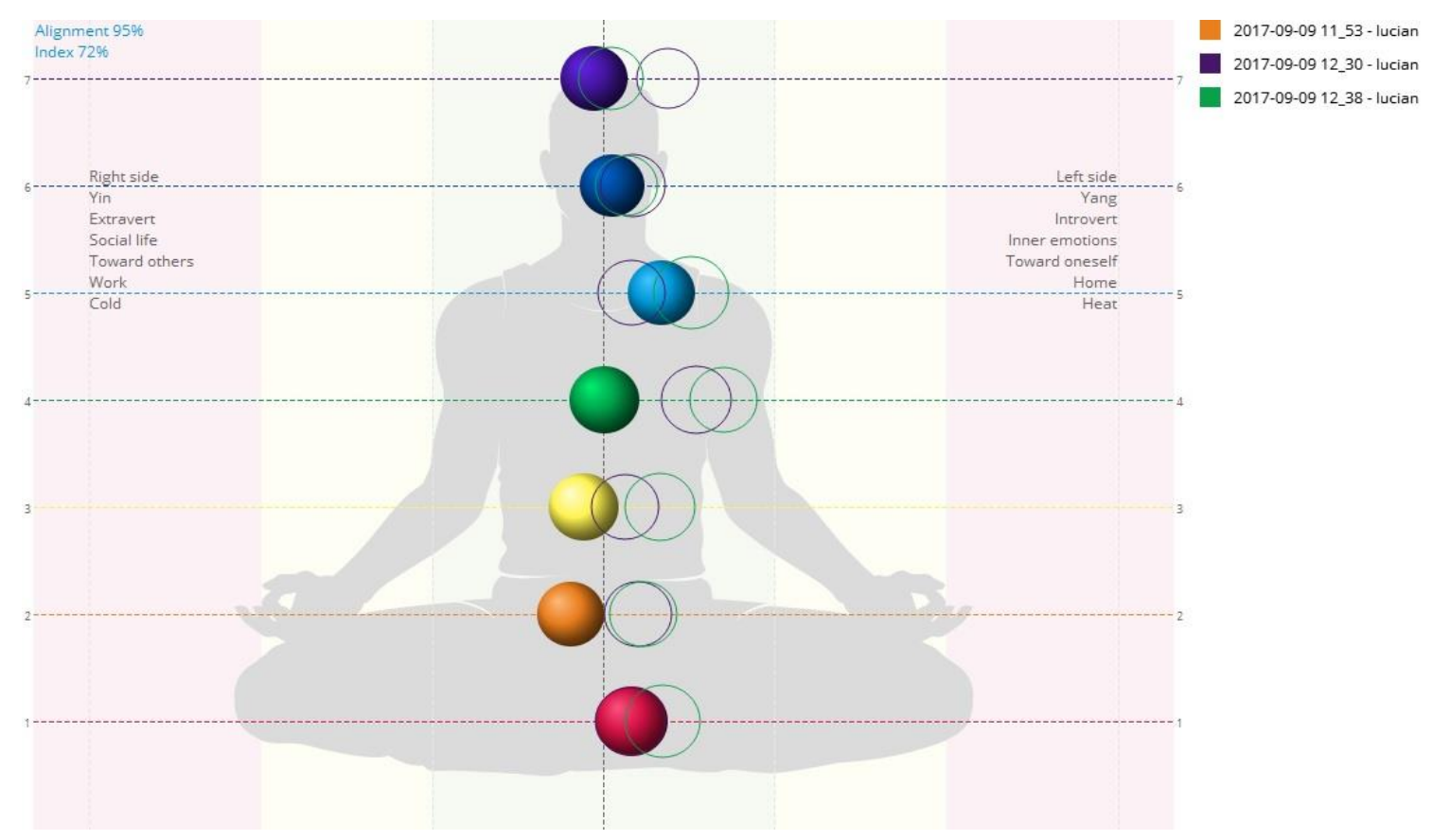

PICBE | 588

Figure 8. Electro Photonic Imaging Device state data, recorded in September 2017 (The article's first author)

Source: Authors' own research.

We can see that only two other energy centers, the third and the fourth, have the same type of movement.

Table 2. The seven energy centers alignment for the last 3 measurements

\begin{tabular}{|l|c|c|c|}
\hline \multicolumn{1}{|c|}{ Energy centre } & \multicolumn{3}{|c|}{ Alignment } \\
\hline The first, red & First position & Second position & Third position \\
\hline The second, orange & 94.60 & 94.96 & 88.65 \\
\hline The third, yellow & $\mathbf{9 3 . 5 4}$ & $\mathbf{9 3 . 3 4}$ & $\mathbf{9 2 . 4 0}$ \\
\hline The fourth, green & 95.93 & 95.91 & 89.18 \\
\hline The fifth, blue & 99.93 & 82.14 & 76.83 \\
\hline The sixth, ultramarine & 88.99 & 94.65 & 83.03 \\
\hline The seventh, violet & 98.60 & 94.55 & 95.83 \\
\hline
\end{tabular}

Source: Authors' own research.

The second energy centre was moved from 93.54, at the left part of the vertical symmetry axe of the body to 93.34 , at the right part of the axe and then it reached the third position at 92.40, as presented in Table 2 . So, for energy centre number 2 , the difference of the extreme values is now of $14.06 \%$. centre.

We consider the value high enough to justify the wanted displacement of this

The first position in the table corresponds to the orange empty circle which is covered by the full disks, the second to the violet empty circle and the third to the green empty circle, as shown in Figure 8.

These results, from the second part of the article, are remarkable and completely original results, too. They were obtained and measured, maybe, for the first time in the world. They can be reached without moving the body or any part of it and without any external influence. 
These measurements show that we can control the position of the second energy centre just because we want to do that. So, in principle, we can then control the positions of all the seven energy centers, one by one. If we can control their positions, we can control the whole balance of the body. This is one of the bases to control everything in our being.

And so, an incredible personal control and level of performance and also a high level of happiness can be achieved. These are very useful in business excellence and not only.

\section{Conclusions}

The authors presented original results with great importance for the functioning of the human being. They highlight what can be done by everybody to improve the own state and to be able to be a high-performer, not only in business, but also in life in general.

The authors emphasized that the human being can have better "functioning parameters", less stress, higher energy, better general and organs balance, even if the person advances in age.

We can also see that for the second type of experiments, taking into account the movement of all the energy main centers presented in both tables, only the second one has the same tendency of displacement. The others behave completely different. This is of course due to the fact that the displacement of the second energy centre was a controlled one. This thing proves, obviously, that we can control the movement of this energy center and, in this way we can increase our general self control.

Due to all the original measurements justified by the values of the results presented, the authors revealed that a full control of the personal body can be obtained, which is an essential condition for performance and business excellence.

The authors proved, with this occasion, that humans can repair themselves. As the time passes, it is not sufficient to let the body repair itself. The body will try to repair all the damages and will fight with the invasions, of course, but with less success in time. You must help it continuously with diverse techniques to be healthy and highperforming.

The suggestions of the authors about their original techniques presented here can be very useful to achieve these goals, as all our measurements demonstrate.

\section{References}

Mândrea, L., Torp A. (2016) Energia umană și posibilități de remediere proprii, Human Energy and Self Remedy Possibilities, EUB International Conference, April 4-5, Bucharest, Romania.

Mândrea, L., Chirilă, A. (2017) The Complete Human Being, Energy and Soul, the $11^{\text {th }}$ International Conference on Business Excellence, Strategies, Complexity and Energy in Changing Times, 30-31 March 2017, Bucharest, Romania.

Mândrea, L., Chirilă, A. (2017) The Complete Human Being, Energy and Soul, Proceedings of the International Conference on Business Excellence, published by De Gruyter Open, 2017-08-26, DOI: https://doi.org/10.1515/picbe-2017-0046, pp. 427-436, Volume 11, Issue 1, ISSN 2558-9652.

Mândrea, L. (2014) Percepții extrasenzoriale, Sufletul în corpul uman, Extra-sensorial Perceptions, The Soul in the Human Body, Editura Tornada, Tornada Publishing House, Bucharest 2014. 
Mândrea, L. (2011) Comportamentul sufletului în corpul uman, The Behaviour of the Soul in the Human Body, Editura Tornada, Tornada Publishing House, Bucharest 2011.

Petre R.A. (2014) Globii luminoși din fotografii, Glowing Orbs in Photos, Explicații fizice și paranormale, Physical and Paranormal Explanations, Ediția a doua, Second Edition, SPIRITUS.RO, Colecția MANIFESTĂRI ALE SPIRITELOR, SPIRITS MANIFESTATIONS Collection.

Klaus H., Miceal L. (November 6, 2007) The Orb Project, Paperback - Deckle Edge. Meg Blackburn Losey, Magnificent Orbs, spiritlite.com.

Jeremy L. (2011) Orbs of Light - Soaking In the Light of the Spirit, Identity Network, (C) Copyright - Identity Network- Jeremy Lopez / Identity Network, Inc. (885767857308).

Mândrea, L., Curta I. (2017) The Modification of the Energy Level of the Human Being, Influences on the Psychic State and Health, A XVII-a Conferință internațională multidisciplinară "Profesorul Dorin PAVEL - fondatorul hidroenergeticii românești", The 17th International Multidisciplinary Conference "Professor Dorin PAVEL”, Sebeș-Alba, 2-3 iunie 2017, pg. 117-124, ISSN 2067-7138.

Mândrea, L., Costea, M., Torp, A. (2015) The Energy Emissions Produced by the Human Being and their Practical Use, THE $9^{\text {th }}$ INTERNATIONAL SYMPOSIUM ON ADVANCED TOPICS IN ELECTRICAL ENGINEERING, May 7-9, 2015, Bucharest, Romania, 978-1-4799-7514-3/15/\$31.00 (C2015 IEEE, P.260-264.

Marosy, Z.I. (2010) Contribuţii la studiul influenței câmpurilor electromagnetice asupra materiei, Contributions at the Study of the Electromagnetic Fields Influence on the Matter, Teză de doctorat, PhD. Thesis, Universitatea Transilvania din Braşov.

Becker, R., Selden, G. (1985) The Body Electric, Electromagnetism and the Foundation of Life, Morrow Publishing House, NY, 1985.

Dobson P., O'Keffe E. (2000) Investigations into Stress and it's Management using the Gas Discharge Visualization Technique, International Journal of Alternative and Complementary Medicine, June 2000.

Dumitrescu, F.I. (1979) Electronografia - Metode electronografice în biologie, Electronography - Electronographic Methods in Biology, Editura Ştiinţifică şi Enciclopedică, Scientific and Encyclopedic Publishing House, Bucharest.

Gerber, R. (2005) Medicina vibraţională, The Vibration Medicine, Editura Elit, Elit Publishing House, ISBN 973-9380-40-9.

Guja, C. (1993) Aurele Corpurilor. Interfeţe cu Cosmosul, The Body's Aura, Cosmos Interfaces, Vol. I, Editura Enciclopedică, Encyclopedic Publishing House, Bucharest, ISBN 973-45-0050-3.

Guja, C. (2000, a) Aurele Corpurilor. Interfețe cu Cosmosul, The Body's Aura, Cosmos Interfaces, Vol. II, Editura Polirom, Polirom Publishing House, Iaşi, ISBN 973-683394-1.

Guja, C. (2000, b) Aura Corpului Uman. Introducere în antropologia individului, The Human Body's Aura, Introduction in the Individual Anthropology, Editura Polirom, Polirom Publishing House, Iași, ISBN 973-683-394-1.

Guja, C. (2008) Antropologie Informaţională, Informational Anthropology, Editura Academiei, Academy Publishing House.

Ionescu-Târgoviște, C. (1986) Acupunctura şi bioenergetica umană, Acupuncture and Human Bio-Energy, Editura Sport Turism, Sport Turism Publishing House.

Lupeanu, A. (2008) Corelaţii între potenţialele bio-electrice, structurile neurovasculare si zonele punctelor de acupunctură reflectate în eficienţa terapeutică a acestor 
locaţii, The Correlations between the Bio-Electric Potentials, Neurovascular Structures and the Puncture Zones of the Accupuncture reflected in the Therapeutical Efficiency of these Locations, Teză de doctorat, PhD. Thesis, Facultatea de Medicină şi Farmacie Oradea, Medicine and Pharmacy Faculty Oradea.

Manu, M.D. (2007) Teoria laserilor biologici, efecte ale câmpurilor electromagnetice optice la nivelul celulei vii din perspectiva biofotonicii, The Biological Laser Theory, Effects of the Optical Electromagnetical Fields on the Level of the Living Cell from the Biopfotonics Perspective, Editura ZBOINA, ZBOINA Publishing House, Iași, ISBN 973- 7639-07-16.

Mămulaș, I. (2008) Teoria câmpului biologic a lui G. Gurwitsch, The Biological Field Theory, Sesiunea anuale de comunicări ştiintifice cu participare internaţională Strategii XXI, Bucharest, secţiunea 13, Acțiuni energo - informaționale, Universitatea Națională de Apărare "Carol I", National Defence University "Carol I" ,ISSN 1844-3095.

Motoyama, H. (2009) Teorii despre Sistemul Chakrelor, Theories about the Chakras System, Editura Excalibur, Excalibur Publishing House, Bucharest, ISBN 978973-1930-22-0.

Korotkov, K., Korotkin, D. (1989) Concentration dependence of gas discharge around drops of inorganic electrolytes, Journal of Applied Physics, 89, (2001), 47324737, doi.org/10.1063/1.1360700.

Korotkov, K. G. (2007) Diagnosis and monitoring of the human energy-informational state and analysis of subtle energies, applying Gas Discharge Visualization technique, based on the Kirlian method, Saint-Petersburg Technical University SPIFMO, Russia, http://gdv-energiecoaching.be/wpcontent/uploads/2012/05/2007 -GDV-Overview-article.pdf.

Korotkov, K. G. (2014) Energy Fields Electro-Photonic Analysis in Humans and Nature. $2^{\text {nd }}$ Edition, Create Space Independent Publishing Platform, April 21.

Yakovleva, E., Korotkov, K. G. (2013) Electro-Photonic Analysis in Medicine. GDV Bioelectro-graph Research, ISBN 978-1481932981.

Mândrea L, Curta I. (2017) The Hysteresis Phenomenon in the Human Bio-Energetic Field, THE $10^{\text {th }}$ INTERNATIONAL SYMPOSIUM ON ADVANCED TOPICS IN ELECTRICAL ENGINEERING, March 23-25, 2017, Bucharest, Romania.

Torp, A., Mândrea, L., Zoltan M., (2016) The Effects of Electronic Devices upon the Human Beings Energetic Structure and the Possible Relation between Increased Stress and Diminished Performance. A XVI-a Conferință internațională multidisciplinară "Profesorul Dorin PAVEL-fondatorul hidroenergeticii românești", The $16^{\text {th }}$ International Multidisciplinary Conference "Professor Dorin PAVEL", Sebeș-Alba, 10-11 iunie 2016, 467-474, ISSN 2067-7138.

Torp, A., Mândrea, L., Cipu, C. (2015) Electro-Photonic Imaging, a Possible Predicting Factor for Academic Performance. Energy Education Science and Technology Part A: Energy Science and Research, Volume (issue) 33(6), 3159-3166.

Korotkov, K. G. (2002) Human Energy Field, Study with GDV Bio-Electronography, BACKBONE PUBLISHING Co., USA, ISBN 096443119X. 